УДК 619:616.99.636.92

(C) 2012

Манжсос О. Ф., доктор біологічних наук, професор

Полтавський університет економіки і торгівлі

Передера О. О., Лавріненко І. В., Передера Р.В., кандидати ветеринарних наук, Жерносік I. А., старший викладач

Полтавська державна аграрна академія

\title{
ДИНАМІКА АКТИВНОСТІ ОКРЕМИХ ФЕРМЕНТІВ СИРОВАТКИ КРОВІ ЗА ЕКСПЕРИМЕНТАЛЬНОГО ІНВАЗУВАННЯ КРОЛІВ ЗБУДНИКОМ E. STIEDAE
}

\section{Рецензент - кандидат ветеринарних наук П. І. Локес}

\begin{abstract}
Розвиток печінкової форми еймеріозу кролів характеризується біохімічними змінами показників сироватки крові. Показники активності ферментів сироватки крові - АсАТ, АлАТ, ЛДГ, ГГТП, ЛФ

- на початкових стадіях захворювання не були специфічними, а лише вказували на компенсаторні реакиії клітин печінки та жовчовивідних шляхів.

На шосту добу експерименту, незважаючи на відсутність клінічних ознак, реєстрували підвищення активності АлАТ, АсАТ, ГГТП, щзо свідчить про порушення структури печінки. Домінуюче значення АлАТ над АсАТ у хворих кроленят на шістнадияту добу дослідження є наслідком розвитку гострих запальних прочесів у паренхімі печінки. Підвищення активності ГГТП, АлАТ, АсАТ у сироватці крові відповідає наявності синдрому цитолізу, щзо розвивається після порушення иілісності клітин, у яких містяться дані ферменти: гепатоцитів і епітеліальних клітин жовчовивідних шляхів.
\end{abstract}

Ключові слова: еймеріоз, кролі, біохімічні показники, ГГТП, АсАТ, АлАТ.

Постановка проблеми. Еймеріоз кролів $є$ одним із паразитарних захворювань, що характеризується значними збитками у галузі кролівництва. Так, Eimeria stiedae паразитує в печінці кролів і викликає значні, часто незворотні зміни цього органа. Діагностувати еймеріоз кролів за клінічними ознаками досить важко, поскільки характерні клінічні прояви виявляють лише перед загибеллю тварин. Недостатньо вивченими на сьогодні залишаються й зміни в організмі кролів у різні періоди розвитку E. stiedae. Особливо бракує інформації стосовно біохімічних змін сироватки крові у хворих кроленят при паразитуванні окремих видів еймерій.

Аналіз основних досліджень і публікацій, у яких започатковано розв'язання проблеми. Патогенна дія еймерій різнобічно вивчалася при захворюванні у різних видів тварин $[1,3-5,7]$. При цьому реєстрували зниження рівня загаль- ного білка сироватки крові, вмісту альбумінів, гемоглобіну, каталази, цукру та підвищення рівня гамаглобулінів [4, 7]. У кролів найчастіше вивчалися зміни при кишковій та змішаній формах еймеріозу кролів. У науковій літературі зустрічаються окремі повідомлення щодо змін у сироватці крові кролів за різних патологічних станів $[2,6]$.

Мета дослідження: вивчення патогенної дії E. stiedae у різні періоди розвитку.

Завданням досліджень було визначення активності ферментів, що характеризують стан печінки, жовчовивідних шляхів та загальний стан організму кроленят у різні стадії паразитування E. stiedae.

Матеріал і метод досліджень. Матеріалом для біохімічних досліджень була сироватка крові, яку отримували $з$ камер серця. Дослідження проводили на третю, шосту, десяту та шістнадцяту добу після експериментального інвазування кролів збудником E. stiedae. У сироватці крові визначали: активність ферментів АлАТ, ЛДГ, AcAT, лужної фосфатази, ГГТП. Біохімічні показники сироватки крові визначали за допомогою біохімічного аналізатора Super Z в умовах сертифікованої лабораторії 4-ї міської лікарні м. Полтава.

Результати досліджень. Функціональний стан печінки характеризує специфічний тест гамаглутамілтранспептидаза (ГГТП). Активність цього ферменту в сироватці крові на третю добу після інвазії дещо знижувалася й становила $12,6 \pm 0,56$ проти $17,6 \pm 1,14$ од./л $(\mathrm{p}<0,01)$ у тварин контрольної групи (див. табл.). Зниження у сироватці крові активності специфічних ферментів може свідчити про збільшення інтенсивності компенсаторних реакцій на ранніх стадіях запального процесу. В результаті підвищеної потреби у цих ферментах самих клітин печінки їх рiвень у крові дещо знижений. 
ВЕТЕРИНАРНА МЕДИЦИНА

Динаміка активності ГГТП, АЛАТ і АсАТ, ЛФ та ЛДГ за експериментального відтворення еймеріозу

\begin{tabular}{|c|c|c|c|c|c|}
\hline \multirow[b]{2}{*}{ Показники } & \multirow{2}{*}{$\begin{array}{c}\text { Контроль } \\
(\mathrm{n}=5)\end{array}$} & \multicolumn{4}{|c|}{ Дослід $(\mathrm{n}=5)$} \\
\hline & & $\begin{array}{l}\text { третя } \\
\text { доба }\end{array}$ & $\begin{array}{c}\text { шоста } \\
\text { доба }\end{array}$ & $\begin{array}{l}\text { десята } \\
\text { доба }\end{array}$ & $\begin{array}{c}\text { шістнадцята } \\
\text { доба }\end{array}$ \\
\hline ГГТП, од./л & $17,6 \pm 1,14$ & $12,6 \pm 0,56^{\bullet}$ & $160,4 \pm 8,65^{*}$ & $38,4 \pm 2,97^{*}$ & $493,0 \pm 8,32^{*}$ \\
\hline АлАТ, од./л & $43,6 \pm 1,34$ & $29,7 \pm 1,84^{*}$ & $79,4 \pm 3,27^{*}$ & $71,7 \pm 0,67 *$ & $106,0 \pm 1,80^{*}$ \\
\hline АсАТ од./л & $26,6 \pm 0,73$ & $21,3 \pm 1,81^{\circ}$ & $91,6 \pm 0,72 *$ & $39,3 \pm 1,74 *$ & $44,8 \pm 1,79^{*}$ \\
\hline ЛДГ, од./л & $119,0 \pm 2,39$ & $552,0 \pm 9,05^{*}$ & $237,2 \pm 6,26^{*}$ & $292,0 \pm 4,39 *$ & $358,0 \pm 3,03 *$ \\
\hline ЛФ, од./мЛ & $123,2 \pm 5,70$ & $396,8 \pm 10,23 *$ & $427,0 \pm 6,21^{*}$ & $498,0 \pm 12,17 *$ & $987,0 \pm 8,27^{*}$ \\
\hline
\end{tabular}

Примітка: ${ }^{\circ}-\mathrm{p}<0,05 ;^{\bullet}-\mathrm{p}<0,01 ; *-\mathrm{p}<0,001$

Стрімке підвищення активності ГГТП на шосту добу експерименту (майже у десять разів), порівняно з третьою добою, вказувало на перші специфічні прояви захворювання. На десяту добу активність даного ферменту в сироватці крові хворих кролів знизилася порівняно 3 попереднім дослідженням і становила $38,4 \pm 2,97$ од./л ( $<<0,001)$, що у 2,2 разу перевищувало показник по групі контролю. На шістнадцяту добу експерименту активність ГГТП у крові хворих кролів у 28 разів $(\mathrm{p}<0,001)$ перевищувала аналогічний показник у здорових тварин і становила $493,0 \pm 8,32$ проти $17,6 \pm 1,14$ од./л.

Індикаторними для печінки $€$ ферменти аспартатамінотрансфераза (АсAТ) та аланінамінотрансфераза (АлАТ). Дані ферменти переносять аміногрупи від аспарагінової кислоти (АсАТ) та аланіну (АлАТ) на альфа-кетоглутарову кислоту. Вони локалізуються у гіалоплазмі клітин та в мітохондріях (AcAT). Трансферази є досить чутливими й інформативними показниками ураження печінки. На третю добу після експериментальної інвазії активність АлАТ у крові хворих тварин знизилася на $32,0 \%$ і складала $29,7 \pm 1,84$ проти $43,6 \pm 1,34$ од./л у групі контрольних тварин $(\mathrm{p}<0,001)$. У даний період активність АсАТ у піддослідних кролів була нижчою від аналогічного показника у здорових на $20,0 \% \quad(p<0,05) \quad$ і складала $21,3 \pm 1,81$ проти $26,6 \pm 0,73$ од./л відповідно.

Із розвитком патологічних процесів збільшується кількість гепатоцитів із явищами декомпенсації, у результаті чого порушується їхня структура. На це вказує підвищення активності через шість діб після початку експерменту АлАТ - на 80,0 \%

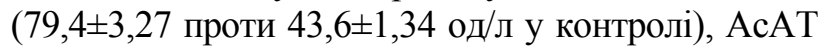
- у 3,4 разу $(91,6 \pm 0,72$ проти $26,6 \pm 0,73$ од./л).

У наступні строки дослідження активність даних ферментів дещо знизилась у групі експериментально інвазованих тварин, порівняно 3 попередніми значеннями, хоча значно перевищувала відповідні показники здорових тварин.
На десяту добу вони дорівнювали $71,7 \pm 0,67$ та $39,3 \pm 1,74$ од./л, що перевищувало аналогічні показники тварин контрольної групи на 64,0 \% та $48,0 \%$, відповідно ( $<<0,001)$.

На шістнадцяту добу експерименту активність АсАТ у сироватці крові хворих тварин була в 1,7 paзу вищою, ніж у тварин контрольної групи $(\mathrm{p}<0,001)$ і становила $44,8 \pm 1,79$ проти $26,6 \pm 0,73$ од./л у здорових тварин. Щодо АлАТ, то іï активність перевищувала норму у 2,4 разу в хворих кролів ( $<<0,001)$. Згідно з одержаними даними, активність цього ферменту досягала $106,0 \pm 1,8$ од./л

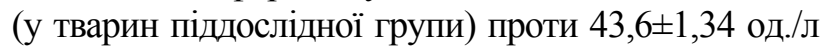
(у групі контролю).

Менш специфічними для визначення функціонального стану печінки $є$ показники активності лужної фосфатази (ЛФ) та лактатдегідрогенази (ЛДГ). Лужна фосфатаза - цинковмісний металопротеїн, який бере участь у мінеральному обміні. Вона розщеплює ефіри ортофосфорної кислоти 3 утворенням неорганічного фосфору. Фермент розміщується в клітинах у зв'язаному з плазматичними мембранами стані. Лужна фосфатаза складається з різних ізоферментів, що локалізуються переважно в епітелії жовчовивідних шляхів, плазматичних мембран гепатоцитів і нейронів, кістках, кишківнику, плаценті, нирках. Лактатдегідрогеназа (ЛДГ) каталізує реакцію перетворення піровиноградної кислоти у молочну.

На третю добу після експериментального зараження активність ЛДГ у крові піддослідних тварин

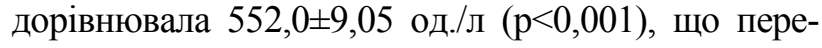
вищувало аналогічний показник у кролів контрольної групи в 4,5 разу (на 78,4 \%); активність лужної фосфатази у цей період у 3,2 разу перевищувала аналогічний показник у тварин контрольної групи й складала $396,8 \pm 10,23$ од./мл проти $123,2 \pm 5,70$ од./мл $(\mathrm{p}<0,001)$. Підвищення активності лужної фосфатази можна пояснити ії інтенсивним синтезом внаслідок подразнення епітелію жовчовивідних шляхів паразитами й токсинами. 
На шосту добу активність ЛДГ знизилася майже вдвічі у порівнянні $з$ попереднім значенням (до 237,2 $\pm 6,26$ од./л), але залишилася достатньовисокою щодо групи контролю й перевищувала аналогічний показник здорових кролів удвічі ( $<<0,001)$. Можна зробити припущення, що даний фермент $є$ більш чутливим до токсичних явищ аніж до запальних процесів в організмі. Підвищення активності лужної фосфатази вказує на наявність інтрагепатитного стазу жовчі.

На шосту добу експерименту у групі піддослідних тварин активність ЛФ підвищилася на 30 од./мл - порівняно з результатом попередніх досліджень - і знаходилася на рівні 427,0土6,21 од./мл у контролі, що у 3,5 разу перевищувало аналогічний показник у здорових тварин $(\mathrm{p}<0,001)$.

У результаті подальших досліджень встановлено підвищення активності ЛДГ у 1,2 разу (до $292,0 \pm 4,39$ од./мл) - на десяту добу експерименту, що у 2,5 разу перевищувало аналогічне значення у здорових кролів, а на шістнадцяту добу експерименту активність даного ферменту підвищилася ще в 1,2 разу стосовно попереднього значення i становила $358,0 \pm 3,03$ од./л ( $<0,001)$.

Цей показник перевищував аналогічний у тварин контрольної групи втричі.

\section{БІБЛІОГРАФІЯ}

1. Качанова С. П. Гистохимическая характеристика Eimeria tenella и некоторых тканей хозяина при кокцидиозе: автореф. дисс. ... канд. вет. наук / С. П. Качанова. - М., 1969. - 19 с.

2. Новинская В. Ф. Эймериоз кроликов / В. Ф. Новинская, Ю. М. Давидов, Ю. В. Красников // Ветеринария. - 1983. - №7. - С. 49.

3. Потоиький М. Кокцидіози ссавців (Coccidiosises mammalium) / Микола Потоцький // Ветеринарна медицина України. - 2007. - №3. C. 24-26.

4. Сванбаев С. К. К вопросу о биохимических и морфологических изменениях состава крови при экспериментальном кокцидиозе крупного рогатого скота / С. К. Сванбаев, 3. И. Горбунова // Известия АН Каз. ССР. (Серия биол.). - 1968. -
На десяту добу експерименту активність ЛФ почала стрімко зростати: вона складала $498,0 \pm 12,17$ од./мл, що перевищувало значення контролю у чотири рази, а на шістнадцяту добу даний показник досягнув 987,0土8,27 од./мл, що у вісім разів перевищувало норму $(\mathrm{p}<0,001)$.

Висновки. Біохімічні показники сироватки крові залежать від стадії паразитування E. stiedae в організмі кролів.

Зміни активності ферментів сироватки крові на початкових стадіях захворювання не $\epsilon$ специфічними, вони вказують на компенсаторну реакції клітин печінки та жовчовивідних шляхів.

На шосту добу експерименту, незважаючи на відсутність клінічних ознак, реєстрували підвищений рівень білірубіну, підвищення активності АлАТ, АсАТ, ГГТП, що свідчить про порушення структури печінки.

Домінуюче значення активності АлАТ над АсАТ у хворих кроленят на шістнадцяту добу дослідження вказує на розвиток гострих запальних процесів у паренхімі печінки, а підвищення активності вищеназваних ферментів у сироватці крові відповідає наявності синдрому цитолізу, що розвивається внаслідок порушення цілісності гепатоцитів та епітеліальних клітин жовчовивідних шляхів.

№3. - C. 38-41.

5. Слободян Р. О. Антигенний вплив збудників еймеріозу телят на біохімічні показники сироватки крові / Р. О. Слободян // Наук. зб. НАУ. 2006. - Вип. 98. - С. 177-181.

6. Смутнев П. В. Влияние глицериновой нагрузки на метаболизм кроликов, больных эймериозом / П. В. Смутнев // Материалы конф., посвященной 119-й годовщине со дня рождения академика Н. И. Вавилова - «Вавиловские чтения 2006». - M. - C. 92-95.

7. Халиков Ф. Р. Биохимические показатели крови и мышечной ткани при цекальном кокцидиозе кур // Автореф. дисс. ... канд. вет. наук. Куйбышев. - 1969. - 17 с. 